\title{
Muscicapines, a New Class of Guaiane-Type Sesquiterpene Alkaloids from Croton muscicapa
}

\author{
Vicente T. de Araújo-Júnior ${ }^{a}$, Marcelo S. da Silva ${ }^{a}$,Emídio V. Leitão da-Cunha ${ }^{a, b}$, Maria de Fátima \\ Agra $^{a}$, Petrônio F. de Athayde-Filho ${ }^{a}$, Ivo J. Curcino Vieira ${ }^{c}$, Raimundo Braz-Filho ${ }^{c}$, and José M. \\ Barbosa-Filho $*$, a \\ ${ }^{a}$ Laboratório de Tecnologia Farmacêutica, Universidade Federal da Paraíba, CP 5009, \\ 58051-970 João Pessoa - PB, Brazil \\ ${ }^{b}$ Departamento de Farmácia e Biologia, Universidade Estadual da Paraíba, 58100-000 Campina Grande - PB, Brazil \\ ${ }^{c}$ Setor de Química de Produtos Naturais-LCQUI, Universidade Estadual do Norte Fluminense,
} 28015-620 Campos - RJ, Brazil

\begin{abstract}
Três novos alcalóides sesquiterpênicos do tipo guaiano, muscicapina A (1), muscicapina B (2) e muscicapina C (3) foram isolados das raízes de Croton muscicapa. As estruturas foram elucidadas através de análises espectroscópicas, principalmente RMN de 1D e 2D e espectrometria de massas. Este é o primeiro relato na literatura de uma nova classe de alcalóides sesquiterpênicos com esqueleto guaiano.
\end{abstract}

Three new guaiane-type sesquiterpene alkaloids, muscicapine A (1), muscicapine B (2), and muscicapine C (3) were isolated from the roots of Croton muscicapa. The structures were established by analysis of spectroscopic data, mainly $1 \mathrm{D}$ and 2D NMR and MS. This is the first report of a new class of guaiane-type sesquiterpene alkaloids.

Keywords: Croton muscicapa, Euphorbiaceae, guaiane sesquiterpene alkaloid, muscicapines

\section{Introduction}

Plants of the genus Croton (Euphorbiaceae), widely distributed throughout tropical areas, are used in South America as sources of traditional medicines for the treatment of wounds, inflammation, and cancer. ${ }^{1}$ Their species are known to be rich in terpenoids (essential oils and diterpenes) and alkaloids (indole and mainly isoquinoline derivatives). ${ }^{2}$

In a search for new drugs from plants of the genus Croton, a previous work described the isolation of clerodane and labdane diterpenes from Croton polyandrus Spreng $^{3}$ and diterpenes and alkaloids from Croton moritibensis Baill. ${ }^{4}$ In this work, the chemical investigation of Croton muscicapa Müll. Arg., a native shrub to Northeastern Brazil, popularly known as "velame de cheiro", is reported. From the ethanolic extract of the roots, four alkaloids (1-4) were isolated through a series of partitions followed by chromatographic procedures. ${ }^{5}$ The alkaloids isolated were the known nicotine derivative anabasine (4) and three new

*e-mail: jbarbosa@ltf.ufpb.br

guaiane-type sesquiterpene alkaloids $\mathbf{1}, \mathbf{2}$ and $\mathbf{3}$ which are described here for the first time (Figure 1).

The literature on components of essential oil refers to an enormous number of lower terpenes, but no mono- and

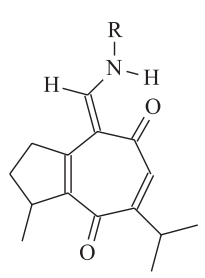

$1 \mathrm{R}=\mathrm{H}$

$$
\text { 1a } \mathrm{R}=\mathrm{Ac}
$$<smiles>c1cncc(C2CCCCN2)c1</smiles>

4

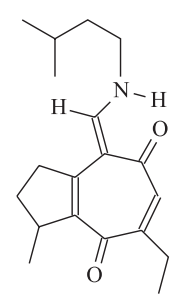

2

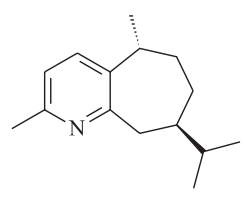

5

Figure 1.
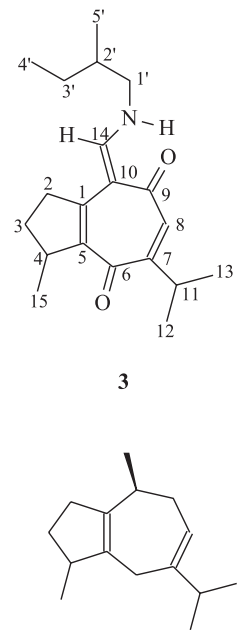

6 
sesquiterpene alkaloids. However, alkaloids derived from diterpenes and steroids are widespread in plants. To the best of our knowledge the alkaloid with the carbon skeleton closest to the guaiane-type sesquiterpene alkaloids is epiguaipyridine (5) isolated from the essential oil of Pogostemon pachouli. ${ }^{6}$

\section{Results and Discussion}

The known alkaloid anabasine (4) was identified by spectral data, mainly ${ }^{1} \mathrm{H}$ and ${ }^{13} \mathrm{C}$ NMR spectra, and comparison with literature values. ${ }^{7}$

Alkaloid 1 was obtained as an amorphous yellow solid and showed $[\alpha]_{\mathrm{D}}^{20}-44^{\circ}\left(\mathrm{CHCl}_{3}, c 0.05\right)$. The IR spectrum revealed bands at $v_{\max } 3366(\mathrm{~N}-\mathrm{H}), 1650$ (conjugated carbonyl group stretching) and 2932-2833 $\mathrm{cm}^{-1}(\mathrm{C}-\mathrm{H}$ stretching). ${ }^{8}$ The EIMS of $\mathbf{1}$ (Scheme 1) showed a molecular ion peak at $\mathrm{m} / \mathrm{z} 245$ daltons $\left([\mathrm{M}]^{+*}\right)$ which, together with ${ }^{1} \mathrm{H}$ and ${ }^{13} \mathrm{C}$ (HBBD and APT) NMR spectral data (Tables 1 and 2), were in agreement with the molecular formula $\mathrm{C}_{15} \mathrm{H}_{19} \mathrm{NO}_{2}$, compatible with a sesquiterpenoid skeleton with an additional nitrogen atom. ${ }^{6}$

The ${ }^{1} \mathrm{H}$ and ${ }^{13} \mathrm{C}$ NMR spectral data of $\mathbf{1}$, including ${ }^{1} \mathrm{H}-{ }^{13} \mathrm{C}-$ $\mathrm{COSY}^{\mathrm{n}} J_{\mathrm{CH}}(\mathrm{n}=1, \mathrm{HMQC} ; \mathrm{n}=2$ and $3, \mathrm{HMBC}$ ) (Table 2), are in agreement with a guaiane sesquiterpene skeleton oxidized with the formation of an enamine group between $\mathrm{C}-10\left(\delta_{\mathrm{C}}\right.$ $110.30)$ and $\mathrm{C}-14\left(\delta_{\mathrm{C}}\right.$ 159.27). The location of the enamine group at $\mathrm{C}-10\left(\delta_{\mathrm{C}} 110.30\right)$ was unequivocally deduced by HMBC correlations between $\mathrm{H}-14\left(\delta_{\mathrm{H}} 7.89\right)$ and carbons C$10\left(\delta_{\mathrm{C}} 110.30,{ }^{2} J_{\mathrm{CH}}\right)$ and C-9 $\left(\delta_{\mathrm{C}} 188.32,{ }^{3} J_{\mathrm{CH}}\right)$. The presence of a primary enamine was suggested by the correlations of $\mathrm{H}$ $14\left(\delta_{\mathrm{H}} 7.89, \mathrm{dd}, J 8.2\right.$ and $\left.13.9 \mathrm{~Hz}\right)$ and amino group $\mathrm{NH}_{2}\left(\delta_{\mathrm{H}}\right.$ $11.71)$ in the ${ }^{1} \mathrm{H}-{ }^{1} \mathrm{H}-\mathrm{COSY}$ spectrum. The 2-ene-1,4-dione system was confirmed by HMBC correlations between the carbonyl carbon C-9 $\left(\delta_{\mathrm{C}} 188.32,\right)$ and hydrogens H-14 $\left(\delta_{\mathrm{H}}\right.$ $\left.7.89,{ }^{3} J_{\mathrm{CH}}\right)$ and $\mathrm{H}-8\left(\delta_{\mathrm{H}} 6.76,{ }^{2} J_{\mathrm{CH}}\right)$ (Table 2). The isopropyl group, was characterized by ${ }^{1} \mathrm{H}$ NMR spectra (1D and $2 \mathrm{D}^{1} \mathrm{H}-$ $\left.{ }^{1} \mathrm{H}-\mathrm{COSY}\right)$ by two doublets $(\mathrm{J} 6.7 \mathrm{~Hz})$ at $\delta_{\mathrm{H}} 1.15$ and $1.14\left(\mathrm{H}_{3}-\right.$ 12 and $\left.\mathrm{H}_{3}-13\right)$ and a multiplet at $\delta_{\mathrm{H}} 3.38(\mathrm{H}-11)$. This together with $\mathrm{HMQC}\left(\mathrm{CH}_{3}-12\right.$ and $\mathrm{CH}_{3}-13: \delta_{\mathrm{H}} / \delta_{\mathrm{C}} 1.15 / 22.84$ and $1.14 /$ 22.41; $\left.\mathrm{CH}-11: \delta_{\mathrm{H}} / \delta_{\mathrm{C}} 3.38 / 30.42\right)$ and $\mathrm{HMBC}$ correlations (Table 2) of C-7 with both methyl groups $\mathrm{H}_{3}-12\left(\delta_{\mathrm{H}} 1.15\right.$, $\left.{ }^{3} J_{\mathrm{CH}}\right)$ and $\mathrm{H}_{3}-13\left(\delta_{\mathrm{H}} 1.14,{ }^{3} J_{\mathrm{CH}}\right), \mathrm{H}-8\left(\delta_{\mathrm{H}} 6.76,{ }^{2} J_{\mathrm{CH}}\right)$ and $\mathrm{H}-11$ $\left(\delta_{\mathrm{H}} 3.38,{ }^{2} J_{\mathrm{CH}}\right)$ confirm the presence of the isopropyl group at $\mathrm{C}-7$. The presence of the methyl group $\mathrm{CH}_{3}-15$ at position $\mathrm{C}$ 4, was determined by the doublet signal at $\delta_{\mathrm{H}} 1.17(\mathrm{~J} 6.9 \mathrm{~Hz})$ observed in the ${ }^{1} \mathrm{H}$ (1D and $2 \mathrm{D}{ }^{1} \mathrm{H}-{ }^{1} \mathrm{H}-\mathrm{COSY}$ ) NMR spectra (Table 1) and by the HMBC correlations with the quaternary $\mathrm{sp}^{2}$ carbon C-5 $\left(\delta_{\mathrm{C}} 139.73\right)$ (Table 2). Additional heteronuclear long-range correlations observed in the $\mathrm{HMBC}$ are summarized in Table 2.
The alkaloids 2, $[\alpha]_{\mathrm{D}}^{20}-6^{\circ}\left(\mathrm{CHCl}_{3}, c 0.02\right)$, and $\mathbf{3},[\alpha]_{\mathrm{D}}^{20}$ $-9^{\circ}\left(\mathrm{CHCl}_{3}, c\right.$ 0.05), were separated by recycling HPLC using reverse phase silica gel. Analysis of the spectral data of $\mathbf{1}, \mathbf{2}$, and $\mathbf{3}$ allowed their identification as guaiane sesquiterpene alkaloids containing the common basic skeleton. The EIMS of isomers $\mathbf{2}$ and $\mathbf{3}$ (Scheme 1) showed molecular ion peaks at $\mathrm{m} / \mathrm{z} 315$ daltons $\left([\mathrm{M}]^{*+}\right)$, which, together with ${ }^{1} \mathrm{H}$ and ${ }^{13} \mathrm{C}$ (HBBD and APT) NMR spectral data (Table 2), suggested the deduction of the molecular formula $\mathrm{C}_{20} \mathrm{H}_{29} \mathrm{NO}_{2}$. Comparison of this molecular formula with that of $\mathbf{1}\left(\mathrm{C}_{15} \mathrm{H}_{19} \mathrm{NO}_{2}\right)$ suggested the presence of an additional reduced isoprene moiety $\mathrm{C}_{5} \mathrm{H}_{10}\left(\mathrm{C}_{20} \mathrm{H}_{29} \mathrm{NO}_{2}\right.$ $\mathrm{C}_{15} \mathrm{H}_{19} \mathrm{NO}_{2}=70$ daltons) in $\mathbf{2}$ and $\mathbf{3}$.

The isopentyl group bonded to the nitrogen atom of $\mathbf{2}$ was characterized as 3-methylbutyl by the doublet signal at $\delta_{\mathrm{H}} 0.96\left(\mathrm{~J} 6.6 \mathrm{~Hz}, \mathrm{H}_{3}-4^{\prime}\right.$ and $\left.\mathrm{H}_{3}-5^{\prime}\right)$ and multiplet signals at $\delta_{\mathrm{H}} 1.74\left(\mathrm{H}-3^{\prime}\right), 1.60\left(\mathrm{H}_{2}-2^{\prime}\right)$ and $3.50\left(\mathrm{H}_{2}-1^{\prime}\right)$ in the ${ }^{1} \mathrm{H}(1 \mathrm{D}$ and $2 \mathrm{D}{ }^{1} \mathrm{H}-{ }^{1} \mathrm{H}-\mathrm{COSY}$ ) NMR, which showed heteronuclear correlations with ${ }^{13} \mathrm{C}$ signals at $\delta_{\mathrm{C}} 22.28\left(\mathrm{CH}_{3}-4^{\prime}\right.$ and $\mathrm{CH}_{3}$ 5'), 25.64 (CH-3'), $39.47\left(\mathrm{CH}_{2}-2^{\prime}\right)$, and $49.13\left(\mathrm{CH}_{2}-1^{\prime}\right)$ in the HMQC spectrum (Table 1). The location of this group at the nitrogen atom [ $\mathrm{N}$-(3-methylbutyl) derivative of $\mathbf{1}]$ was suggested by the ${ }^{1} \mathrm{H}$ and ${ }^{13} \mathrm{C}$ chemical shifts of the methylene group $\mathrm{CH}_{2}{ }^{\prime}{ }^{\prime}\left(\delta_{\mathrm{H}} 3.50\right.$ and $\left.\delta_{\mathrm{C}} 49.13\right)$ and confirmed by HMBC correlations between $\mathrm{CH}-14\left(\delta_{\mathrm{C}} 160.40\right)$ and $2 \mathrm{H}-1$ ' $\left(\delta_{\mathrm{H}} 3.50,{ }^{3} J_{\mathrm{CH}}\right)($ Table 2$)$. Additional HMBC correlations are indicated in Table 2.

The presence of a 2-methylbutyl group in $\mathbf{3}$ was deduced by the signals at $\delta_{\mathrm{H}} 1.01\left(\mathrm{~d}, J 6.9 \mathrm{~Hz}, \mathrm{H}_{3}-5^{\prime}\right), 0.95(\mathrm{t}, J 7.7$, $\left.\mathrm{H}_{3}-4^{\prime}\right), 1.27$ ( $\left.\mathrm{m}, \mathrm{H}_{2}-3^{\prime}\right), 1.48$ (m, H-2'), and 3.38/3.31 (m, $\mathrm{H}_{2}-1$ ') in the ${ }^{1} \mathrm{H}$ (1D and $\left.2 \mathrm{D}{ }^{1} \mathrm{H}-{ }^{1} \mathrm{H}-\mathrm{COSY}\right) \mathrm{NMR}$ spectra, which was confirmed by the HMQC and HMBC spectra (Tables 1 and 2). HMBC correlations between $\mathrm{CH}-14\left(\delta_{\mathrm{c}}\right.$ $160.87)$ and $\mathrm{H}_{2}{ }^{-1}{ }^{\prime}\left(\delta_{\mathrm{H}} 3.38\right.$ and 3.31), together with the ${ }^{13} \mathrm{C}$ chemical shift of the methylene group $\mathrm{CH}_{2}-1$ ' $\left(\delta_{\mathrm{C}}\right.$ 56.91) (Table 2) were used to locate the 2-methylbutyl group at the nitrogen atom [ $N$-(2-methylbutyl) derivative of 1]. Additional heteronuclear long-range couplings are summarized in Table 2. The alkaloids were named muscicapine A, muscicapine $\mathrm{B}$, and muscicapine $\mathrm{C}$, respectively.

To our knowledge, the muscicapines represent the first members of a new class of guaiane-type sesquiterpene alkaloids in plants. Biogenetically, their precursor should be the guaiadiene 6 , which had the $\mathrm{CH}_{3}-14$ oxidized to the corresponding aldehyde, which, after reductive amination, incorporated the amino groups. The introduction of a double bond between C-10 and C-14 by NADP/FAD and oxidation of C-6 and C-9 furnishes muscicapine A (1). The other two muscicapines B (2) and C (3) probably originate by condensation of the aldehyde with the corresponding 
3-methyl and 2-methyl butylamines probably originated by descarboxylation of leucine and isoleucine, respectively.

\section{Experimental}

\section{General procedures}

${ }^{1} \mathrm{H}$ NMR (500 MHz) and ${ }^{13} \mathrm{C}$ NMR (125 MHz) were recorded at room temperature with a Bruker NMR spectrometer (DRX 500) with an inverse multinuclear 5 $\mathrm{mm}$ probe head equipped with a shielded gradient coil. The spectra were recorded in $\mathrm{CDCl}_{3}$, and the solvent signals (7.27 and $77.0 \mathrm{ppm}$ ) were used as references. The chemical shifts $(\delta)$ are given in ppm, and the coupling constant $(J)$ in Hz. All programs used for performing the 2D NMR experiments are part of the Bruker library. EIMS data were determined on a JEOL mass spectrometer using direct insertion probe at $70 \mathrm{eV}$. IR spectra were obtained using $\mathrm{KBr}$ pellets in a Shimadzu Infrared Spectrometer model FTIR-8300. The optical rotation $[\alpha]$ value was obtained
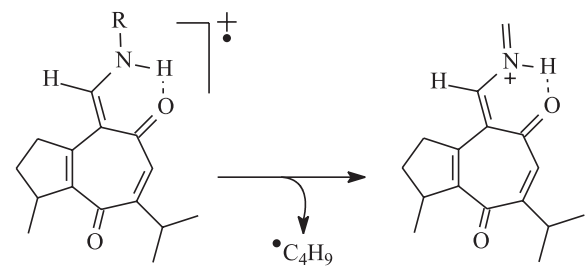

1. $(\mathrm{R}=\mathrm{H}) \mathrm{m} / \mathrm{z} 245(73 \%)$ 2. $\left(\mathrm{R}=\mathrm{C}_{5} \mathrm{H}_{11}\right) m / z 315(87 \%)$ 3. $\left(\mathrm{R}=\mathrm{C}_{5} \mathrm{H}_{11}\right) \mathrm{m} / \mathrm{z} 315(79 \%)$

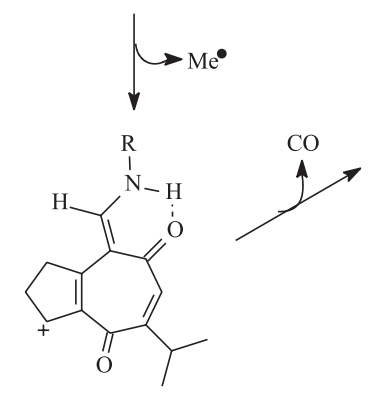

1. $(\mathrm{R}=\mathrm{H}) \mathrm{m} / z 230(29 \%)$ 2. $\left(\mathrm{R}=\mathrm{C}_{5} \mathrm{H}_{11}\right) m / z 300(45 \%)$ 3. $\left(\mathrm{R}=\mathrm{C}_{5} \mathrm{H}_{11}\right) m / z 300(41 \%)$ 2. $m / z 258(38 \%)$ 3. $m / z 258(8 \%)$

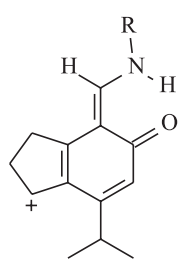

1. $(\mathrm{R}=\mathrm{H}) \mathrm{m} / z 202(100 \%)$ 2. $\left(\mathrm{R}=\mathrm{C}_{5} \mathrm{H}_{11}\right) \mathrm{m} / z 272(100 \%)$ 3. $\left(\mathrm{R}=\mathrm{C}_{5} \mathrm{H}_{11}\right) m / z 272(100 \%)$

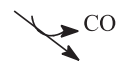

2. $\left(\mathrm{R}=\mathrm{C}_{5} \mathrm{H}_{11}\right) m / z 244(42 \%)$ 3. $\left(\mathrm{R}=\mathrm{C}_{5} \mathrm{H}_{11}\right) m / z 244(94 \%)$

Scheme 1. Proposed fragmentation mechanisms of 1, 2 and $\mathbf{3}$ (only principals peaks).

Table 1. ${ }^{1} \mathrm{H}(400 \mathrm{MHz})$ and ${ }^{13} \mathrm{C}(100 \mathrm{MHz})$ NMR for muscicapine A (1), $N$-acetylmuscicapine (1a), muscicapine B (2), and muscicapine C (3), in $\mathrm{CDCl}_{3}$ as solvent

\begin{tabular}{|c|c|c|c|c|c|c|c|c|}
\hline \multirow[b]{2}{*}{$\mathbf{C}$} & \multicolumn{2}{|r|}{1} & \multicolumn{2}{|r|}{$1 \mathbf{a}$} & \multicolumn{2}{|r|}{2} & \multicolumn{2}{|r|}{3} \\
\hline & $\delta_{\mathrm{C}}$ & $\delta_{\mathrm{H}}$ & $\delta_{\mathrm{C}}$ & $\delta_{\mathrm{H}}$ & $\delta_{\mathrm{C}}$ & $\delta_{\mathrm{H}}$ & $\delta_{\mathrm{C}}$ & $\delta_{\mathrm{H}}$ \\
\hline 1 & 146.99 & - & 144.48 & - & 147.03 & - & 147.03 & - \\
\hline 5 & 139.73 & - & 143.65 & - & 139.65 & - & 139.65 & - \\
\hline 6 & 186.56 & - & 183.67 & - & 185.55 & - & 185.55 & - \\
\hline 7 & 157.14 & - & 165.29 & - & 157.86 & - & 157.86 & - \\
\hline 9 & 188.32 & - & & - & 186.54 & - & 186.54 & - \\
\hline 10 & 110.30 & - & 121.75 & - & 109.16 & - & 109.16 & - \\
\hline Ac & - & - & 172.88 & - & - & - & - & - \\
\hline \multicolumn{9}{|l|}{$\mathrm{CH}$} \\
\hline 4 & 42.53 & $3.42(\mathrm{~m})$ & 42.00 & $3.58-3.30(\mathrm{~m})$ & 42.14 & $3.44(\mathrm{~m})$ & 42.14 & $3.44(\mathrm{~m})$ \\
\hline 8 & 135.42 & $6.76(\mathrm{~s})$ & 132.71 & $6.57(\mathrm{~s})$ & 135.37 & $6.83(\mathrm{~s})$ & 135.37 & $6.82(\mathrm{~s})$ \\
\hline 11 & 30.42 & $3.38(\mathrm{~m})$ & 31.16 & $3.58-3.30(\mathrm{~m})$ & 30.32 & $3.40(\mathrm{~m})$ & 30.32 & $3.40(\mathrm{~m})$ \\
\hline 14 & 159.27 & $7.89(\mathrm{dd}, 8.2,13.9)$ & 146.34 & $8.07(\mathrm{~d}, 11.4)$ & 160.40 & $7.73(\mathrm{~d}, 13.2)$ & 160.87 & $7.70(\mathrm{~d}, 13.2)$ \\
\hline $2^{\prime}$ & - & - & - & - & - & - & 35.95 & $1.48(\mathrm{~m})$ \\
\hline $3^{\prime}$ & - & - & - & - & 25.64 & $1.74(\mathrm{~m})$ & - & - \\
\hline \multicolumn{9}{|l|}{$\mathrm{CH}_{2}$} \\
\hline $2^{2}$ & 35.88 & $\begin{array}{c}2.96(\mathrm{td}, 15.9,8.1) \\
2.79(\mathrm{ddd}, 15.9 \\
9.1,4.3)\end{array}$ & 35.00 & $3.26(\mathrm{~m}) 3.12(\mathrm{~m})$ & 36.01 & $3.00(\mathrm{~m}) 2.87(\mathrm{~m})$ & 36.01 & $3.00(\mathrm{~m}) 2.87(\mathrm{~m})$ \\
\hline 3 & 30.10 & $2.06(\mathrm{~m}) ; 1.53(\mathrm{~m})$ & 30.24 & $2.85(\mathrm{~m}) ; 1.64(\mathrm{~m})$ & 30.19 & $2.07(\mathrm{~m}) ; 1.55(\mathrm{~m})$ & 30.19 & $2.07(\mathrm{~m}) ; 1.55(\mathrm{~m})$ \\
\hline 1 ' & - & - & - & - & 49.13 & $3.50(\mathrm{~m})$ & 56.91 & $3.38(\mathrm{~m}) ; 3.31(\mathrm{~m})$ \\
\hline $2^{\prime}$ & - & - & - & - & 39.47 & $1.60(\mathrm{~m})$ & - & - \\
\hline $3^{\prime}$ & - & - & - & - & - & - & 26.80 & $1.27(\mathrm{~m})$ \\
\hline \multicolumn{9}{|l|}{$\mathrm{CH}_{3}$} \\
\hline 12 & 22.84 & $1.15(\mathrm{~d}, 6.7)$ & 22.52 & $1.20(\mathrm{~d}, 6.6)$ & 22.65 & $1.13(\mathrm{~d}, 6.6)$ & 22.65 & $1.13(\mathrm{~d}, 6.6)$ \\
\hline 13 & 22.41 & $1.14(\mathrm{~d}, 6.7)$ & 22.07 & $1.18(\mathrm{~d}, 6.6)$ & 22.23 & $1.13(\mathrm{~d}, 6.6)$ & 22.23 & $1.13(\mathrm{~d}, 6.6)$ \\
\hline 15 & 19.53 & $1.17(\mathrm{~d}, 6.9)$ & 18.63 & $1.20(\mathrm{~d}, 6.2)$ & 19.23 & $1.16(\mathrm{~d}, 7.0)$ & 19.23 & $1.16(\mathrm{~d}, 7.0)$ \\
\hline $4^{\prime}$ & - & - & - & - & 22.28 & $0.96(\mathrm{~d}, 6.6)$ & 11.38 & $0.95(t, 7.7)$ \\
\hline 5 & - & - & - & - & 22.28 & $0.96(\mathrm{~d}, 6.6)$ & 17.13 & $1.01(\mathrm{~d}, 6.9)$ \\
\hline $\mathrm{H}_{2} \mathrm{~N}$ & - & $11.71(\mathrm{~s})$ & - & - & - & - & - & - \\
\hline $\mathrm{HN}$ & & - & - & 12.67 (brd) & - & 12.93 (brs) & - & 13.01 (brs) \\
\hline Ac & - & - & 21.74 & $1.89(\mathrm{~s})$ & - & - & - & - \\
\hline
\end{tabular}


Table 2. Long-range correlations observed in the HMBC $\left({ }^{\mathrm{n}} J_{\mathrm{CH}}, \mathrm{n}=2\right.$ and 3) spectra of muscicapine A (1), muscicapine B (2), and muscicapine C (3), in $\mathrm{CDCl}_{3}$ as solvent and residual $\mathrm{CDCl}_{3}{ }^{\mathrm{a}}$

\begin{tabular}{|c|c|c|c|c|c|c|c|c|c|}
\hline \multirow[b]{2}{*}{ C } & \multicolumn{3}{|c|}{1} & \multicolumn{3}{|c|}{2} & \multicolumn{3}{|c|}{3} \\
\hline & $\delta_{\mathrm{C}}$ & ${ }^{2} J_{\mathrm{CH}}$ & ${ }^{3} J_{\mathrm{CH}}$ & $\delta_{\mathrm{C}}$ & ${ }^{2} J_{\mathrm{CH}}$ & ${ }^{3} J_{\mathrm{CH}}$ & $\delta_{\mathrm{C}}$ & ${ }^{2} J_{\mathrm{CH}}$ & ${ }^{3} J_{\mathrm{CH}}$ \\
\hline 1 & 146.99 & $2 \mathrm{H}-2$ & $\mathrm{H}-14$ & 147.03 & $2 \mathrm{H}-2$ & $\mathrm{H}-14$ & 147.03 & $2 \mathrm{H}-2$ & $\mathrm{H}-14$ \\
\hline 5 & 139.73 & & $2 \mathrm{H}-3 ; 3 \mathrm{H}-15$ & 139.65 & & $2 \mathrm{H}-3 ; 3 \mathrm{H}-15$ & 139.65 & & $2 \mathrm{H}-2 ; 3 \mathrm{H}-15$ \\
\hline 6 & 186.56 & & & 185.55 & & H-8 & 185.55 & & H-8 \\
\hline 7 & 157.14 & H-8; H-11 3 & $3 \mathrm{H}-12 ; 3 \mathrm{H}-13$ & 157.86 & H-8; H-11 & $3 \mathrm{H}-12 ; 3 \mathrm{H}-13$ & 157.86 & H-8; H-11 & $3 \mathrm{H}-12 ; 3 \mathrm{H}-15$ \\
\hline 9 & 188.32 & H-8 & H-14 & 186.54 & & H-14 & 186.54 & & H-14 \\
\hline 10 & 110.30 & H- 14 & H-8 & 109.16 & $\mathrm{H}-14$ & $\mathrm{H}-8$ & 109.16 & H- 14 & H-8 \\
\hline \multicolumn{10}{|l|}{$\mathrm{CH}$} \\
\hline 4 & 42.53 & $2 \mathrm{H}-3 ; 3 \mathrm{H}-15$ & $2 \mathrm{H}-2$ & 42.14 & $3 \mathrm{H}-15$ & & 42.14 & $3 \mathrm{H}-15$ & \\
\hline 8 & 135.42 & & H-11 & 135.37 & & $\mathrm{H}-11$ & 135.37 & & H-11 \\
\hline 11 & 30.42 & $3 \mathrm{H}-12 ; 3 \mathrm{H}-13$ & & 30.32 & $3 \mathrm{H}-12 ; 3 \mathrm{H}-13$ & H-8 & 30.32 & $3 \mathrm{H}-12 ; 3 \mathrm{H}-13$ & H-8 \\
\hline 14 & 159.27 & & & 160.40 & & $2 \mathrm{H}-1$ & 160.87 & & $2 \mathrm{H}-1$ \\
\hline $2^{\prime}$ & - & - & - & - & - & - & 35.95 & $2 \mathrm{H}-1^{\prime} ; 3 \mathrm{H}-5^{\prime}$ & $3 \mathrm{H}-4^{\prime}$ \\
\hline 3, & - & - & - & 25.64 & $3 \mathrm{H}-4^{\prime} ; 3 \mathrm{H}-5^{\prime}$ & $2 \mathrm{H}-1$ & - & - & - \\
\hline \multicolumn{10}{|l|}{$\mathrm{CH}_{2}$} \\
\hline 2 & 35.88 & $\mathrm{H}-3 \mathrm{a}$ & & 36.01 & & & 36.01 & & \\
\hline 3 & 30.10 & $2 \mathrm{H}-2$ & & 30.19 & $2 \mathrm{H}-2$ & & 30.19 & $2 \mathrm{H}-2$ & \\
\hline 1 ' & - & - & - & 49.13 & $2 \mathrm{H}-2$ ' & H-14 & 56.91 & & H-14; $3 \mathrm{H}-5$, \\
\hline 2 ' & - & - & - & 39.47 & $2 \mathrm{H}-1$ & $3 \mathrm{H}-14^{\prime} ; 3 \mathrm{H}-5{ }^{\prime}$ & - & - & - \\
\hline $3^{\prime}$ & - & - & - & - & - & - & 26.80 & $3 \mathrm{H}-4^{\prime}$ & $2 \mathrm{H}-1^{\prime} ; 3 \mathrm{H}-5^{\prime}$ \\
\hline \multicolumn{10}{|l|}{$\mathrm{CH}_{3}$} \\
\hline 12 & 22.84 & & & 22.65 & H-11 & & 22.65 & H-11 & \\
\hline 13 & 22.41 & & & 22.23 & H-11 & & 22.23 & H-11 & \\
\hline 15 & 19.53 & & H-3a & 19.23 & & & 19.23 & & \\
\hline $4^{\prime}$ & - & & & 22.28 & & & 11.38 & & \\
\hline 5, & - & & & 22.28 & & & 17.13 & H-2' & $2 \mathrm{H}-1^{\prime}$ \\
\hline $\mathrm{H}_{2} \mathrm{~N}$ & - & & & - & & & - & & \\
\hline $\mathrm{HN}$ & & & & - & & & - & & \\
\hline
\end{tabular}

\footnotetext{
${ }^{a}$ Number of hydrogens bound to carbon atoms deduced by comparative analysis of HBBD- and DEPT- ${ }^{13} \mathrm{C}$ NMR spectra. Chemical shifts and coupling constants $(J)$ obtained from $1 \mathrm{D}^{1} \mathrm{H}$ NMR spectrum. Superimposed ${ }^{1} \mathrm{H}$ signals are described without multiplicity and chemical shifts deduced by HMQC (Table 1) and ${ }^{1} \mathrm{H}-{ }^{1} \mathrm{H}-\mathrm{COSY}$ spectra.
}

on a Perkin Elmer model 343 Digital Polarimeter using $\mathrm{CHCl}_{3}$ as solvent. $\mathrm{CC}$ was carried out over alumina (activity II-III, 70-230 mesh ASTM) using different mixtures of chloroform and methanol gradient. The alkaloids were purified by repeated PTLC ( $1 \mathrm{~mm}$ thick, 20 x $20 \mathrm{~cm}$ Si gel $\mathrm{PF}_{254}$ plates) and recycling HPLC using Shimadzu Chromatograph in reverse phase (ODS, Shim-Pack $(\mathrm{H})$, $5 \mu \mathrm{m}, \mathrm{MeOH}, 3.0 \mathrm{~mL} \mathrm{~min}^{-1}$ ).

\section{Plant material}

Croton muscicapa Muell. Arg. was collected in the "caatinga" vegetation near the municipality of Caicó, State of Rio Grande do Norte, Brazil in April 2002. A voucher specimen (AGRA 5995) is deposited in the Herbarium Prof. Lauro Pires Xavier (JPB), Universidade Federal da Paraíba, Brazil.

\section{Extraction and isolation}

The dried and powdered roots ( $2 \mathrm{~kg}$ ) of C. muscicapa were extracted at room temperature using $\mathrm{EtOH}$ 95\%, furnishing, after solvent evaporation under vacuum, 73.5 $\mathrm{g}$ of extract. This extract was dissolved in $3 \% \mathrm{HCl}$, filtered over celite and extracted with $\mathrm{CHCl}_{3}$. The aqueous phase was alkalinized with $\mathrm{NH}_{4} \mathrm{OH}$ and extracted again with $\mathrm{CHCl}_{3}$ furnishing $3.2 \mathrm{~g}$ of a residue. The residue was chromatographed on a neutral aluminum oxide column with a gradient of $\mathrm{MeOH}$ in $\mathrm{CHCl}_{3}$ yielding seventy fractions. Alkaloid $4(583 \mathrm{mg})$ was purified from fractions 5-8 (1.0 g) after rechromatography on silica gel PTLC using $\mathrm{CHCl}_{3}: \mathrm{MeOH}$ (99.5:0.5). Fractions 42-49 (15.0 mg) were purified by recycling HPLC using reverse phase with $\mathrm{MeOH}$ as solvent to give alkaloid $\mathbf{2}(2.1 \mathrm{mg})$ and alkaloid $3(1.7 \mathrm{mg})$. Alkaloid $1(5.8 \mathrm{mg})$ was purified from the fractions 67-70 $(15.0 \mathrm{mg})$ using a silica gel column and a gradient of $\mathrm{MeOH}$ in $\mathrm{CHCl}_{3}$ as eluent. Alkaloid $\mathbf{1}$ was acetylated with acetic anhydride in the presence of pyridine (1:2) overnight at room temperature to furnish the monoacetate 1a $(2.3 \mathrm{mg})$.

\section{Muscicapine A (1)}

$$
\mathrm{C}_{15} \mathrm{H}_{19} \mathrm{NO}_{2} \text {; red oil; }[\alpha]^{20}{ }_{\mathrm{D}}-44^{\circ}\left(\mathrm{CHCl}_{3}, c 0.05\right) ; \mathrm{IR}
$$


(KBr) $v_{\max } / \mathrm{cm}^{-1} 3366,2932,2833$ and 1650); EIMS (70 eV) $\mathrm{m} / \mathrm{z}$ (rel. int.): $245\left(73, \mathbf{M}^{+*}\right), 230$ (29), 202 (100), 174 (14), 91 (12), 79 (11), 77 (16), 53 (13); NMR data ( ${ }^{1} \mathrm{H}$ and ${ }^{13} \mathrm{C}$ NMR, ${ }^{1} \mathrm{H}-{ }^{1} \mathrm{H}$ COSY, ${ }^{1} \mathrm{H}-{ }^{13} \mathrm{C}$ HMQC and ${ }^{1} \mathrm{H}-{ }^{13} \mathrm{C}$ HMBC) are given in Tables 1 and 2.

Muscicapine A acetate (1a)

Acetylation of $\mathbf{1}(4 \mathrm{mg})$ with acetic anhydride $(0.3 \mathrm{~mL})$ in pyridine $(0.5 \mathrm{~mL})$ and work-up in the usual way afforded 1a $(3.1 \mathrm{mg})$ as a yellow oil. NMR data $\left({ }^{1} \mathrm{H}\right.$ and ${ }^{13} \mathrm{C}$ NMR) are given in Table 1.

\section{Muscicapine B (2)}

$\mathrm{C}_{20} \mathrm{H}_{29} \mathrm{NO}_{2}$; yellow oil; $[\alpha]^{20}{ }_{\mathrm{D}}-6^{\circ}\left(\mathrm{CHCl}_{3}, c 0.02\right)$; EIMS (70 eV) $\mathrm{m} / z$ (rel. int.): 315 (87, $\mathrm{M}^{+*}$ ), 300 (45), 287 (15), 273 (18), 272 (100), 258 (38), 244 (42), 230 (20), 216 (13), 202 (27), 187 (13), 55 (13), 43 (69), 41 (43); NMR data $\left({ }^{1} \mathrm{H}\right.$ and ${ }^{13} \mathrm{C}$ NMR, ${ }^{1} \mathrm{H}-{ }^{1} \mathrm{H}$ COSY, ${ }^{1} \mathrm{H}^{-13} \mathrm{C}$ HMQC and ${ }^{1} \mathrm{H}^{-13} \mathrm{C}$ HMBC) are given in Tables 1 and 2.

\section{Muscicapine C (3)}

$\mathrm{C}_{20} \mathrm{H}_{29} \mathrm{NO}_{2}$; yellow oil; $[\alpha]^{20}{ }_{\mathrm{D}}-9^{\circ}\left(\mathrm{CHCl}_{3}, c 0.05\right)$; EIMS (70 eV) m/z (rel. int.): 315 (79, $\left.\mathrm{M}^{+*}\right), 300$ (41), 273 (18), 272 (100), 258 (8), 245 (18), 244 (94), 230 (16), 228 (12), 216 (13), 202 (18), 187 (20), 91 (13), 77 (12), 55 (15), 43 (850, 41 (49); NMR data $\left({ }^{1} \mathrm{H}\right.$ and ${ }^{13} \mathrm{C}$ NMR, ${ }^{1} \mathrm{H}-{ }^{-1} \mathrm{H}$ COSY, ${ }^{1} \mathrm{H}-{ }^{13} \mathrm{C}$ HMQC and ${ }^{1} \mathrm{H}-{ }^{13} \mathrm{C}$ HMBC) are given in Tables 1 and 2.

\section{Acknowledgments}

The authors are grateful to the Programa de Apoio ao Desenvolvimento Científico e Tecnológico (PADCT)/ Financiadora de Estudos e Projetos (FINEP), Instituto do Milênio do Semi-Árido (IMSEAR), CNPq and FAPERJ for grants, and to CNPq for research fellowships.

\section{References}

1. Magalhães, A. F.; Tozzi, A. M. G. A.; Magalhães, E. G.; Moraes, V. R. D.; Phytother. Res. 2000, 14, 156.

2. Southon, I. W.; Buckingham, J.; Dictionary of Alkaloids, Chapman and Hall: London, 1989.

3. Araújo-Júnior, V. T.; Navarro, P. A.; Silva, M. S.; Cunha, E. V. L.; Agra, M. F.; Gray, A. I.; Barbosa-Filho, J. M.; Ciencia 2002, 10, 286.

4. Araújo-Júnior, V. T.; Silva, M. S.; Cunha, E. V. L.; Agra, M. F.; Silva-Filho, R. N.; Barbosa-Filho, J. M.; Braz-Filho, R.; Pharm. Biol. 2004, 42, 62.

5. Barbosa-Filho, J. M.; Cunha, E. V. L.; Cornélio, M. L.; Dias, C. S.; Gray, A. I.; Phytochemistry 1997, 44, 959.

6. Büchi, G.; Goldman, I. M.; Mayo, D. W.; J. Am. Chem. Soc. 1966, 88, 3109.

7. Yang, C. M.; Tanner D. D.; Can. J. Chem. 1997, 75, 616.

8. Silverstein, R. M.; Webster, F. X.; Spectrometric Identification of Organic Compounds, $6^{\text {th }}$ ed., John Wiley \& Sons, Inc.: New York, 1998. 